\title{
Hubungan Coping dan Resiliensi pada Perempuan Kepala Rumah Tangga Miskin
}

\author{
Ayu Citra Pratiwi, Hirmaningsih \\ Fakultas Psikologi Universitas Islam Negeri Sultan Syarif Kasim Riau \\ email: nig153@yahoo.co.id
}

\begin{abstract}
Abstrak
Menjadi perempuan kepala rumah tangga miskin merupakan situasi yang dapat menimbulkan stres dan kecemasan. Agar mampu menghadapi situasi tersebut perempuan kepala rumah tangga memerlukan reiliensi. Resiliensi adalah kemampuan untuk mengatasi situasi sulit yang ada dalam hidup dan melanjutkan perkembangan normal. Penelitian ini bertujuan untuk mengkaji hubungan coping dan resiliensi pada perempuan kepala rumah tangga miskin. Hipotesis yang diajukan adalah terdapat hubungan antara coping dan resiliensi pada perempuan kepala rumah tangga miskin. Subjek penelitian ini sebanyak 70 orang. Alat ukur yang digunakan adalah skala coping yang disusun berdasarkan konsep Lazarus dan Folkman (1984) dan skala resiliensi yang disusun berdasarkan konsep Reivich dan Shatte (2002). Data dianalisis menggunakan teknik analisis Product Moment, hasil penelitian menunjukkan terdapat hubungan positif antara coping dan resiliensi yang nilai koefisien korelasinya sebesar 0,525 dengan $p=0,000$ $(p<0.01)$. Hal ini berarti semakin baik kemampuan coping, maka semakin baik juga resiliensi pada perempuan kepala rumah tangga miskin.
\end{abstract}

Kata Kunci : coping, resiliensi, perempuan kepala rumah tangga miskin

\section{Relationship Between Coping and Resilience in Poor Women Heads of households}

\begin{abstract}
Be women heads of poor households is situations can make stress and anxiety. To be able to deal with the situation, women heads of household head requires reiliensi. Resilience is ability to cope with difficult situations that exist in normal life. This research aims to know the relationship coping and resiliensi on women heads of households are poor. Hypothesis asked is there a relationship between coping and resilience women head poor households. The subject in this study as much as 70 person. Measuring instrument used in this study is based on concept of coping scale Lazarus and Folkman (1984) and scale resiliensi based on the concept of Reivich and Shatte (2002). Analysis techniques use Product Moment, research results indicate that there is a positive relationship between coping and the silience. Koefisien Of correlation value of 0.525 with $p=0.000(p<0.01)$. This means the more coping, then the better it also resilience female heads of poor households.
\end{abstract}

Keywords: coping, resiliensi, women heads of poor households

\section{Pendahuluan}

Data dari World Bank (2015) jumlah rumah tangga yang dikepalai perempuan di Indonesia sebanyak 12,9 persen pada tahun 2007 dan meningkat menjadi 14,8 persen pada tahun 2012. Hingga 2013, tidak kurang dari sembilan juta rumah tangga di Indonesia dikepalai oleh perempuan. Lebih dari separuh diantaranya adalah kelompok masyarakat termiskin di Indonesia. Perempuan yang mengepalai rumah tangga mengalami stres yang lebih tinggi daripada perempuan lain dan memiliki kualitas hidup yang lebih rendah. Peran sebagai perempuan kepala rumah tangga memiliki dampak langsung pada stres, gangguan mental dan penyakit fisik (Farahmand dkk, 2015)

Masalah utama rumah tangga yang dikepalai perempuan dinyatakan dalam bentuk kesulitan ekonomi, kurangnya pengetahuan untuk urusan ekonomi keluarga, sikap negatif masyarakat terhadap rumah tangga yang dikepalai perempuan, kekhawatiran terhadap masa depan anak-anak dan intesintas konflik yang tinggi (Khosravi, 2001).

Meskipun terjadi perpisahan dalam keluarga (divorce) baik akibat kematian, perceraian, sakit dan perpisahan akibat perang, penyakit dan bencana alam tidak dapat di- 
hindarkan, banyak perempuan yang mampu terus mempertahankan hidupnya dan menyesuaikan diri dengan keadaannya (Marlia, 2010). Kemampuan individu untuk bangkit kembali dari keterpurukan yang terjadi dalam perkembangannya disebut resiliensi (Sibert, 2005). Sibert (2005) menjelaskan bahwa individu yang resilien dapat mengatasi perasaan dengan baik saat ditimpa masalah bahkan sulit untuk diterima.

Resiliensi sangat penting untuk menjaga kesinambungan hidup secara optimal. Perempuan sebagai kepala rumah tangga yang memiliki resiliensi yang tinggi akan mampu segera bangkit dan memulihkan dirinya dan keadaan. Namun perempuan kepala rumah tangga dengan resiliensi rendah akan cenderung membutuhkan waktu yang agak lama untuk mampu menerima dan bangkit dari cobaan hidup tersebut. Hal ini berkaitan dengan faktor resiko dan faktor protektif yang dimiliki seseorang dalam menghadapi kondisi-kondisi sulit dalam hidupnya (Siebert, 2005).

Menurut Ungar (2008) resiliensi memiliki makna sebagai suatu kemampuan individu untuk mengatasi kesulitan dan melanjutkan perkembangan normalnya seperti semula. Menurut Reivich dan Shatte (2002) resiliensi adalah kemampuan untuk mengatasi dan beradaptasi terhadap kejadian yang berat atau masalah yang terjadi dalam kehidupan. Bertahan dalam keadaan tertekan, dan bahkan berhadapan dengan kesengsaraan (adversity) atau trauma yang dialami dalam kehidupannya. Aspek relisiensi ada tujuh yaitu 1) regulasi emosi, yaitu adalah kemampuan untuk tetap tenang di bawah kondisi yang menekan (Reivich \& Shatte, 2002).2) pengendalian impuls,yaitu kemampuan Individu untuk mengendalikan keinginan, dorongan, kesukaan, serta tekanan yang muncul dari dalam diri (Reivich \& Shatte, 2002),3) optimisme, yaitu individu yang optimis, optimisme adalah ketika individu melihat bahwa masa depannya cemerlang (Reivich \& Shatte, 2002),4) causal analysis, yaitu kemampuan individu untuk mengidentifikasikan secara akurat penyebab dari permasalahan yang perempuan kepala rumah tangga hadapi, 5). empati, yaitu dengan kemampuan individu untuk membaca tanda-tanda kondisi emosional dan psikologis orang lain (Reivich \& Shatte, 2005).6) self efficacy,yaitu hasil dari pemecahan masalah yang berhasil. Self efficacy merepresentasikan sebuah keyakinan bahwa individu mampu memecahkan masalah yang kita alami dan mencapai kesuksesan dan, 7) reaching out yaitu kemampuan individu meraih aspek positif dari kehidupan setelah kemalangan yang menimpa (Reivich \& Shatte, 2002).

Individu mampu beradaptasi dan memiliki ketahanan terhadap kondisi yang penuh tekanan apabila individu tersebut melakukan usaha-usaha yang efektif untuk mengatasi masalahnya. Usaha untuk mrnghadapi tekanan tersebut dikenal dengan istilah coping. Coping menurut Lazarus (1993) merupakan usaha kognitif dan perilaku yang dilakukan secara terus-menerus untuk mengatur tekanan dari dalam maupun luar diri yang dinilai mengancam.

Kumpfer (1999) mengatakan coping memiliki peran yang signifikan dalam proses mengembangkan resiliensi. Sehingga dapat dikatakan bahwa coping mempengaruhi resiliensi seseorang. Li (2008) mengatakan bahwa resiliensi merupakan hasil dari penggunaan active coping seperti mencari bantuan dan menyelesaikan masalah.

Menurut Lazarus (dalam Lazarus dan Folkman, 1984) coping adalah usaha kognitif maupun perilaku yang dilakukan terus menerus untuk mengatur tekanan dari dalam maupun luar diri yang dinilai mengancam. Feldman (1999) mendefinisikan coping sebagai usaha yang dilakukan individu untuk mengendalikan, mengurangi, atau belajar menoleransi anvaman yang dapat menimbulkan stres.

\section{Jenis dan Aspek Coping}

Lazarus dan Folkman (1984), Lazarus (1993), dan Folkman dkk (1986) mengklasifikasikan dua jenis coping yaitu:

\section{a. Problem Focused Coping (PFC)}

Problem focused coping (PFC) merupakan strategi coping untuk menghadapi masalah secara langsung melalui tindakan yang ditujukan untuk menghilangkan atau mengubah sumber-sumber stres.

Problem focused coping melibatkan beberapa aspek yakni:

1. Confrontative coping; usaha mengubah keadaan yang dianggap menekan dengan cara yang agresif, tingkat kemarahan yang tinggi, dan pengambilan resiko.

2. Seeking social support; yaitu menggambarkan banyaknya keterangan-keterangan yang berhasil dipelajari untuk di organisasikan menjadi bentuk pengetahuan tertentu yang berkaitan dengan masalah-masalah yang sedang dihadapi.

3. Planful problem solving; usaha untuk mengubah keadaan yang dianggap menekan dengan cara yang hati-hati, bertahap, dan analitis.

\section{b. Emotion Focused Coping (EFC)}

Emotion focused coping merupakan strategi untuk meredakan emosi individu yang ditimbulkan oleh stressor (sumber stres), tanpa berusaha untuk mengubah suatu situasi yang menjadi sumber stres secara langsung. Aspek yang termasuk dalam emotion focused coping, yakni: 
1. Self control yakni usaha mengatur perasaan ketika menghadapi situasi yang menekan.

2. Distancing, yakni melakukan upaya kognitif untuk melepaskan diri dari masalah atau membuat sebuah harapan positif. Usaha untuk tidak terlibat dalam permasalahan, seperti menghindar dari permasalahan seakan tidak terjadi apa-apa atau menciptakan pandangan-pandangan yang positif, seperti menganggap masalah sebagai lelucon.

3. Positive reappraisal yaitu mencoba untuk membuat arti positif dari situasi dalam masa perkembangan kepribadian dan kadang-kadang dilakukan dengan melibatkan sifat yang religius

4. Accepting responsibility yaitu, menyadari tanggungjawab diri sendiri dalam permasalahan yang dihadapi, dan mencoba menerimanya untuk membuat keadaan menjadi lebih baik.

5. Escape/avoidance yaitu, mencoba memikirkan masalah dari keinginan (wishful thinking) serta usaha untuk mengatasi situasi menekan dengan lari dari situasi tersebut atau menghindarinya dengan beralih pada hal lain yang menyenangkan seperti makanan, minuman, merokok, ataupun menggunakan obat-obatan.

\section{Hipotesis}

Terdapat hubungan positif antara coping dan resiliensi pada perempuan kepala rumah tangga miskin. Artinya, jika kemampuan coping tinggi maka semakin tinggi juga resiliensi pada perempuan kepala rumah tangga. Sebaliknya, jika kemampuan coping rendah maka resiliensi juga rendah.

\section{Metode}

Penelitian ini menggunakan pendekatan korelasional yang bertujuan untuk mengetahui apakah ada hubungan variabel coping $(X)$, dan variabel resiliensi $(Y)$. Jumlah subjek dalam penelitian ini adalah 70 orang, yang merupakan keseluruhan perempuan kepala rumah tangga miskin yang berada di Kelurahan Wonorejo, Kecamatan Marpoyan Damai, Kotamadya Pekanbaru. Pengambilan sampel dilakukan dengan teknik purposive sampling dengan kriteria, yaitu 1) Perempuan kepala rumah tangga, 2) Miskin, yang ditandai dengan menerima bantuan pemerintah dan atau zakat. Alat ukur yang digunakan dalam penelitian ini adalah skala coping yang disusun berdasarkan konsep Lazarus dan Folkman (1984) dan skala resiliensi yang disusun berdasarkan konsep Reivich dan Shatte (2002). Uji Validitas yang digunakan dalam penelitian ini adalah uji validitas isi (content validity).

Pada skala resiliensi setelah dilakukan uji coba (try out) terdapat 21 aitem gugur dan 35 aitem diterima dengan koefisien korelasi total berkisar antara 0,302-0,694 dengan koefisien reliabilitas sebesar 0,925 Pada skala coping setelah uji coba (try out) terdapat 21 aitem gugur dan 28 aitem diterima dengan koefisien korelasi total berkisar 0,310-0,742 dengan koefisien reliabilitas skala coping sebesar 0,926 .

\section{Hasil}

Deskripsi Subjek Penelitian

Tabel.1 Gambaran Umum Subjek Penelitian

\begin{tabular}{llll}
\hline Data Demografi & & $\mathbf{N}$ & $\%$ \\
\hline Tingkat pendidikan & Tidak Tamat SD & 3 & $4,29 \%$ \\
& SD & 24 & 34,29 \\
& SMP & 13 & 18,57 \\
& SMA & 28 & $40 \%$ \\
& S1 & 2 & $2,85 \%$ \\
& & 70 & $100 \%$ \\
\hline
\end{tabular}

\section{Uji Asumsi}

Uji normalitas yang digunakan dalam penelitian ini adalah One-Sample KS, dalam signifikansi $p>0.05$ maka data dikatakan normal.

Berdasarkan hasil uji normalitas diketahui signifikansi (Asymp Sig) 0,177 untuk variabel coping dan 0,116 untuk variabel resiliensi. Berdasasarkan hasil tersebut dapat diambil kesimpulan bahwa sebaran data dalam penelitian menunjukkan distribusi yang normal.
Hasil uji linearitas diperoleh nilai $F$ sebesar 24,334 dengan $P=0,000(P<0,05)$, artinya data variabel dalam penelitian ini linear. Berdasarkan Curve fit diketahui besar koefisien determinasi (Rsq) sebesar 0,275, artinya variabel coping memiliki kontribusi sebesar $27,5 \%$ terhadap variabel resiliensi sedangkan $72,5 \%$ dipengaruhi oleh variabel lain.

\section{Uji Hipotesis}

Pada penelitian ini diperoleh angka taraf signifikan sebesar $0,000(p<0,01)$ dan 
nilai person correlation $(r) \quad 0,525$. Sehingga dapat disimpulkan bahwa hipotesis diterima yang berarti terdapat hubungan antara coping dengan resiliensi. Artinya semakin tinggi ke- mampuan coping, maka semakin tinggi resiliensi pada perempuan kepala rumah tangga miskin.

Tabel 2. Hubungan Jenis Strategi Coping dan Resiliensi

\begin{tabular}{lllll}
\hline Strategi Coping & & & Rsq & P \\
\hline Problem & Focus & 0,4 & 0,24 & 0,0 \\
Coping ${ }^{*}$ Resiliensi & & 97 & 7 & 00 \\
\hline Emotional & Focus & 0,5 & 0,26 & 0,0 \\
Coping*Resiliensi & & 14 & 4 & 00 \\
\hline
\end{tabular}

Berdasarkan tabel 2 ditunjukkan bahwa jenis strategi problem focus coping dan strategi emotional focus coping berkorelasi secara signifikan dengan resiliensi dengan nilai signifikansi $0,000(P<0,01)$ artinya, pada penelitian ini kedua jenis strategi coping yaitu startegi emotional focus coping dan strategi problem focus coping berhubungan dengan resilensi. Adapun besar koefisien determinasi (Rsq) problem focus coping sebesar 0,247 dan emotional focus coping sebesar 0,264 artinya, strategi problem focus coping memiliki sumbangan efektif sebesar $24,7 \%$ terhadap resiliensi sedangkan startegi emotional focus coping memiliki sumbangan efektif sebesar $26,2 \%$. Berdasarkan hal tersebut, dapat disimpulkan bahwa dalam penelitian ini strategi emotional focus coping dan strategi problem focus coping memiliki sumbangan efektif lebih relative sama.

\section{Pembahasan}

Hasil penelitian ini menunjukan terdapat hubungan antara coping dengan resiliensi pada perempuan kepala rumah tangga miskin. Berdasarkan hasil analisis, diperoleh correlation coefficient $(r)=0,525$ dengan $p=$ $0,000(p<0,01)$. Hasil tersebut menunjukkan bahwa ada hubungan positif yang sangat signifikan antara coping dengan resiliensi. Artinya, semakin baik kemampuan coping, maka semakin baik pula kemampuan resiliensi yang dimiliki perempuan kepala rumah tangga miskin.

Hasil penelitian ini sesuai dengan hipotesis yang diajukan oleh peneliti yaitu ada hubungan antara coping dengan resiliensi. Hal ini sejalan dengan penelitian yang dilakukan Kumpfer (1999) bahwa coping memiliki peran yang signifikan dalam proses mengembangkan resiliensi. Demikian pula Rutter dan Rutter (dalam Ditriya, 2012) mengatakan bahwa coping memiliki peran yang signifikan dalam interaksi antara situasi stress dan resiliensi. Taylor (2012) juga mengatakan bahwa coping merupakan salah satu sumber resiliensi untuk melawan stress. Apabila coping meningkat, maka resiliensi seseorang juga akan meningkat (Stenhardt dan Dolbier, dalam Ditriya, 2012).

Lazarus dan Folkman (1984) mengatakan bahwa tidak semua strategi coping tepat digunakan untuk segala situasi. Penggunaan strategi coping tergantung pada siapa yang menggunakan, kapan dan bagaimana strategi coping itu digunakan. Proporsi penggunaan kedua strategi coping relatif bervariasi tergantung pada bagaimana penilaian individu terhadap situasi yang sedang dihadapinya. Wachs (2006) berpendapat bahwa jenis mekanisme coping yang digunakan oleh individu dapat mempengaruhi resiliensi. Berdasarkan hal tersebut, peneliti juga menganalisa hubungan resiliensi dengan strategi problem focus coping dan emotional focus coping. Hasilnya, kedua strategi coping tersebut memiliki hubungan dengan resiliensi dan sumbangan efektif yang relatif sama terhadap resiliensi.

Dua jenis coping yang berbeda dalam mengatasi masalah maka berbeda pula tingkat kemampuan individu untuk membangkitkan kembali percaya diri dan optimisme, atau dapat disebut juga sebagai tingkat resiliensi (Susanto, 2013). Carver dkk (1989) mengatakan bahwa emotional focus coping menjadi efektif karena dapat mencegah individu untuk tenggelam dalam emosi negatif dan membantu individu untuk dapat mengambil tindakan yang proaktif untuk mengatasi emosi negatif yang muncul. Individu menggunakan emotional focus coping ketika berada dalam situasi diluar kendalinya, dimana tidak banyak hal yang dapat dilakukan individu untuk mengatasi masalah yang menekan.

Emotional focus coping diarahkan untuk mengurangi penderitaan emosional seperti menghindar, meminimalisir, menjaga jarak, selektif memilih perhatian, dan mencari nilai positif dari sebuah peristiwa negatif. Pada perempuan kepala rumah tangga miskin, strategi emotional focus coping efektif digunakan ketika dihadapkan pada kehilangan pasangan hidup baik karena kematian maupun bercerai merupakan peristiwa yang 
tidak dapat dikontrol maupun dihindari. Penerimaan akan kondisi sebagai kepala rumah tangga serta tanggungjawabnya, pencarian makna positif dari kondisi sulit yang dialami serta upaya mengontrol perasaan saat berhadapan dengan situasi tidak menyenangkan karena kesulitan ekonomi, status pernikahan, pengasuhan seorang diri, serta masalah lainnya efektif meredakan emosi negatif sehingga perempuan kepala rumah tangga miskin mampu bertahan mengatasi kondisi sulit dan melanjutkan perkembangan normalnya.

Hasil penelitian ini sejalan dengan penelitian Fawcett dkk (dalam Ditriya, 2012) yang menunjukkan emotional facused coping efektif mempengaruhi resiliensi pada istri yang mengalami kekerasan dalam rumah tangga, sehingga dapat bertahan dengan kondisi psikologis yang sehat dalam pernikahan mereka. Penelitian lain dilakukan oleh Rizky (2012) juga menunjukkan bahwa resiliensi berhubungan lebih erat dengan strategi emotional focus coping karena menjadi pasien kanker adalah situasi yang tidak dapat dihindari, sehingga strategi emotional focus coping adalah strategi yang paling efektif digunakan.

Pada umumnya, jika individu yakin dengan sumber daya yang dimiliki dan menilai situasi yang dihadapinya dapat dikendalikan dan diatasi, maka individu cenderung akan menggunakan problem focus coping (Zanden, 1997). Lazarus \& Folkman (1984) menyebutkan bahwa individu melakukan focus problem coping jika ia menilai situasi yang dialaminya bisa diubah atau ia merasa situasi tersebut memiliki tingkat ancaman sedang. Pada perempuan kepala rumah tangga miskin, focus problem coping digunakan ketika dihadapkan pada kesulitan ekonomi yang harus diatasi dengan cara mencari pekerjaan dengan upah yang lebih baik, merencanakan pengeluaran rumah tangga serta meminta saran atau mencari dukungan sosial. Li (2008) mengatakan bahwa resiliensi merupakan hasil dari penggunaan active coping seperti mencari bantuan dan menyelesaikan masalah.

Resiliensi perempuan kepala rumah tangga miskin dalam penelitian ini berada pada kategori rendah dan sedang, artinya perempuan kepala rumah tangga miskin belum cukup mampu untuk bangkit dari situasi sulit yang dihadapi. Sementara itu, kemampuan coping perempuan kepala rumah tangga miskin dalam penelitian ini berada pada kategori rendah, artinya coping yang dilakukan belum adaptif. Hasil ini senada dengan penelitian Susanto (2013) yang membuktikan bahwa individu dengan kemampuan coping yang lebih tinggi akan mempunyai resiliensi yang tinggi.

Subjek dalam penelitian ini berada pada taraf sosial ekonomi, dan tingkat pen- didikan yang rendah, hal ini menjadi salah satu faktor rendahnya kemampuan coping. Ini sesuai dengan pendapat Westbrook (dalam Billilgs dan Moos, 1984) yang mengatakan bahwa seseorang dengan status sosial ekonomi rendah akan menampilkan coping yang kurang aktif, kurang realistis, dan lebih fatal menampilkan respon menolak, dibandingkan dengan seseorang yang status ekonominya lebih tinggi. Kondisi sosial ekonomi disebut sebagai salah satu faktor eksternal yang paling berpengaruh pada coping. Individu yang memiliki uang, terutama jika memiliki kemampuan menggunakannya secara efektif, dapat melakukan coping dengan lebih baik karena sumber daya tersebut membuka banyak pilihan menghadapi hambatan (Lazarus dan Foklman, 1984). Menurut Menaghan (dalam McCrae, 1984) seseorang dengan tingkat pendidikan yang semakin tinggi akan semakin tinggi pula kompleksitas kognitifnya, demikian pula sebaliknya. Hal ini memiliki efek besar terhadap sikap, konsepsi cara berpikir dan tingkah laku individu yang selanjutnya berpengaruh terhadap strategi copingnya.

Berdasarkan perhitungan statistik diperoleh harga koefisien determinan (Rsq) sebesar 0,275 , artinya variabel coping memiliki kontribusi sebesar $27,5 \%$ terhadap variabel resiliensi sedangkan $72,5 \%$ dipengaruhi oleh variabel lain. Faktor pendukung (protective factor) lain yang mempengaruhi resiliensi adalah keterampilan sosial yang kuat, kemampuan interpersonal dan dukungan sosial (Neil dan Dias dalam Ditriya, 2012). Selain itu, penelitian Smokowski (dalam Everall dkk, 2006) mengungkapkan bahwa locus of control berkorelasi positif dengan resiliensi.

\section{Kesimpulan}

Resiliensi merupakan salah satu modal dalam menghadapi bentuk kondisi yang menylitkan seperti kemiskinan. Hasil penelitian menunjukkan bahwa ada hubungan positif yang sangat signifikan antara coping dengan resiliensi. Artinya, semakin baik kemampuan coping, maka semakin baik pula kemampuan resiliensi yang dimiliki perempuan kepala rumah tangga miskin. Berdasarkan hal tersebut, dapat disimpulkan bahwa dalam penelitian ini strategi emotional focus coping dan strategi problem focus coping memiliki sumbangan efektif lebih relative sama artinya kedua coping tersebut dibutuhkan dalam membantu individu lebih resiliens.

\section{Daftar Pustaka}

Azwar, S. (2013). Penyusunan Skala Psikologi. Yogyakarta: Pustaka Belajar Carver, C.S., Scheier, M.F., dan Weintraub, 
J.K. (1989). Assesing Coping Strategies: A Theoritically Based Approach. Journal of Personality and Social Psychology. Vol. 56, No. 2, 267283

Ditrya, S. B. (2012). Hubungan antara Resiliensi dan Coping pada Istri yang Mengalami Kekerasan dalam Rumah Tangga. Skripsi. Depok: Universitas Indonesia.

Everall, R. D., K. Jessica A., and Barbara L. Paulson. (2006). Creating a Future: A Study of Resilience in Suicidal Female Adolescents. Journal of Counseling \& Development. Volume 84.

Farahmand, Mahnaz, Raziyeh M., Farzaneh A. H. (2015). The Social Relationship Pathology of Female-Headed Households and Their Mental Empowerment. International Journal of Review in Life Sciences. JK Welfare \& Pharmascope Foundation. Farahmand et al., Int. J. Rev. Life. Sci., 5(3), 2015, 192-202

Feldman, R. S., (1999). Understanding Psychology (5th edition). New York: McGraw Hill

Khosravi, Z. (2001). Studying of Psychosocial Problems to Famale-headed Household. Journal of Human Sciences University. 10(39) 94-71

Kumpfer, L. K. (1999). Factors and Processes to resilience: The Resilience Frame work. New York: Academic /Plenum

Lazarus, R, dan Folkman, S. (1984). Stress, Appraisal, dan Coping. New York: Spinger Publishing Company, Inc.

Lazarus, R, S. (1993). Coping Theory and Research: Past, Present, and Future. Journal of Psychosomatic Medicine. 55: 234-247

Li, M. (2008). Relationship among Stress, secure Attachment, and Trait of Resilience Among Taiwanes Collage Student. College Student Journal. 42:312-325
McCrae, R.R. (1984). Situasional

Determinant of Coping Responses:

Loss, Threat and Challlenge. Journal of Personality and Social Psychology. Vol. 46, No.4, 919-928

Marlia, Y. S. (2010). Penyesuaian Diri Ibu yang Menjadi Kepala Keluarga. Skripsi. Surakarta: Universitas Sebelas Maret.

Reivich, K dan Shatte, A. (2002). The Resilience Factor: 7 Skills For Overcoming Life's Inevitable Obstacles. New York: Broadway Books

Rizky, C.R. (2012) Hubungan antara Resiliensi dan Coping pada Pasien kanker Dewasa. Skripsi. Depok: Universitas Indonesia

Siebert, A. (2005). The Resiliency Advantages. San Fransisco: Berret-Koehler Publisher Inc.

Susanto, M.D. (2013). Keterlibatan Ayah dalam Pengasuhan, Kemampuan Coping, dan Resiliensi Remaja. Journal Sains dan Praktik Psikologi. 1/2. 101-113.

Taylor. S.E., (1995). Health Psychology. Singapore: Mc Graw Hill.

Unggar, M. (2008). Resilience Across Cultures. British Journal of Social Work. 38 (2), 218-235.

Wachs, T.D. (2006). Cotributions of Temperament to Buffering and sensitization Procesess in Children's Development. New York of Sciences. 1094: 28-39

World Bank. (2015). Female Headed Households ( $\%$ of household with a female headed).http://data.world bank.org/indicator/SP.HOU.FEMA. ZS/countries/1W-ID?display=graph. Diakses tanggal 7 Maret 2016

Zanden, J, W dan Vonder (1997). Human Development (6th edition). New York: Mc. Graw Hill. 